\title{
PETA KONSEP PADA PEMBELAJARAN IPA UNTUK MENINGKATKAN KETERAMPILAN BERFIKIR RASIONAL SISWA SD/MI
}

\author{
Rini Nafsiati Astuti
}

Staf Pengajar pada PGMI Fakultas Tarbiyah UIN Malang

\begin{abstract}
One of the efforts to increase the instructional effectiveness natural science is by developing meaningful learning strategy through the using concept mapping. The objectives of instructional natural science at elementary school is not only learning concept natural science but also to increase thinking and creativity such as recalling, imagining, classifying, generalizing, comparing, evaluating, analyzing, synthesizing, deducing, inferring, skill processused by the experts in order to get and developing nature science.
\end{abstract}

Concept mapping strategy is one of alternative strategy that can give the results to reach learning objectives. With concept mapping, students could interlocked the natural science before and the new natural science by included concepts to the cognition and defined the relationship on an exibhit then united to the wider structure. The good conceptual understanding will help the students in their learning, until the students will be easier to understand the material they learn.

Strategy using concept mapping to increase effectiveness science instructional viewed from achievement and students learning retention, suggested to science's teacher to use concept mapping as one of learning tools. Using concept mapping after instructional is more suggested, although the other strategy more suitable.

Keywords: concept mapping, natural science, thinking and creativity

\section{A. Pendahuluan}

Pendidikan adalah proses mereproduksi sistim nilai dan budaya kearah yang lebih baik antara lain dalam hal pembentukan kepribadian, ketrampilan dan perkembangan intelektual peserta didik. Dalam lembaga formal proses reproduksi sistim nilai dan budaya ini dilakukan terutama dengan mediasi proses belajar mengajar sejumlah mata pelajaran dalam kelas. Salah satu mata pelajaran yang turut berperan penting dalam mendidikkan wawasan, ketrampilan dan sikap ilmiah sejak dini bagi anak adalah mata pelajaran IPA.

Pembelajaran IPA di SD/MI sangat diharapkan oleh masyarakat terutama untuk merespon adanya perubahan-perubahan keadaan yang begitu cepat seperti munculnya internet, benda-benda elektronik dan 
lainnya. Di Indonesia, GBHN telah mencoba mengantisipasi hal tersebut dengan menekankan perlunya iman, budi, pekerti, serta rasionalisme. Proses berfikir rasional selaku insan intelek paripurna menjadi idaman agar mampu menanggapi tantangan masa depan (Salim dalam Soedjatmoko, 1991). Begitu banyak pilihan yang disodorkan dan kita harus membuat keputusan dengan cepat dan benar tanpa kehilangan kewaspadaan terhadap timbulnya dampak negative dari kemajuan sains.

Selain itu, dalam konteks era globalisasi pembelajaran IPA di SD/MI merupakan wahana untuk menghasilkan warga Negara yang melek sains. Para pakar sains sepakat bahwa dengan melibatkan siswa dengan kegiatan IPA sejak dini akan menghasilkan generalisasi dewasa yang melek sains yang dapat menghadapi tantangan hidup dalam dunia yang makin kompetitif, sehingga mereka mampu turut serta memilih dan mengolah informasi untuk digunakan dalam mengambil keputusan.(Yager,993:4; Connor, 1990:6-7; Carin\&Sund,1989:16)

Oleh karena itu diperlukan kemampuan untuk membuat pertimbangan-pertimbangan logis yang mendasar dari keputusan yang diambil atau boleh juga hal tersebut dinyatakan sebagai kemampuan berfikir rasional. Bekal yang diperlukan untuk menguasai kemampuan tersebut mencakup kemampuan mengingat, berimajinasi, mengklasifikasikan, membuat generalisasi, membuat perbandingan, melakukan evaluasi, menganalisis, mensintesis, membuat deduksi, dan membuat inferensi. Dengan dikuasainya sejumlah kemampuan tersebut diharapkan seseorang dapat menggunakan logika berdasarkan bukti yang relevan untuk membentuk gagasan, sikap, tindakan, dalam rangka mencapai tujuan (Lawson,1979).

Kemampuan berfikir rasional merupakan suatu kemampuan yang tidak dapat ditumbuhkan dalam waktu singkat. Kemampuan berfikir rasional ini akan muncul dalam bentuk yang terbaik, jika dikembangkan seiring dengan pertumbuhan intelektual seseorang. Artinya semakin dini kemampuan berfikir mulai dikembangkan, semakin baik. Setelah anak mulai sekolah, maka tugas untuk mengembangkan kemampuan berfikir rasional sebagian besar beralih dari keluarga kepada pihak sekolah, dalam hal ini guru.

Jika kita melihat kembali hakekat IPA yang mempunyai dimensi produk dan dimensi proses. Kita mempelajari konsep-konsep IPA maka kita juga harus tahu cara mendapatkan konsep tersebut. Hal itu disebut dengan dimensi proses (Sumaji, et al.,1998) yaitu sains/IPA adalah suatu deretan konsep serta konsep skema konseptual yang berhubungan satu sama lain, dan yang tumbuh sebagai hasil eksperimentasi dan observasi, serta berguna untuk diamati dan dieksperimentasi lebih lanjut. Dari pernyataan tersebut terlihat bahwa IPA berusaha untuk membangkitkan keinginan manusia untuk meningkatkan pemahaman dan tingkat 
berfikirnya melalui eksplorasi terhadap rahasia alam yang tak habishabisnya.

Proses pembelajaran IPA di SD/MI selama ini belum mencapai hasil yang memuaskan, hal ini diketahui dari masih rendahnya nilai UAN untuk mata pelajaran IPA. Dalam pelaksaan proses pembelajaraan di sekolah kegiatannya mungkin masih berpusat pada guru dan sistem belajarnyapun lebih bersifat hafalan sehingga akan terjadi verbalisme.Siswa yang belajar bersifat hafalan tingkat kebermaknaannya akan relative rendah, namun belajar penerimaan yang bersifat hafalan dapat juga dibuat bermakana. Dahar(1988:137) menyatakan bahwa belajar penerimaan dapat dibuat bermakna, yaitu dengan cara menjelaskan hubungan anatara konsep-konsep.

Untuk dapat mempelajari IPA dengan baik maka diperlukan struktur kognitif yang baik. Struktur kognitif adalah organisasi informasi yang meliputi fakta-fakta, konsep-konsep dan generalisasi-generalisasi yang telah dipelajari dan diingat oleh siswa (Dahar, 1988:134). Struktur kognitif yang baik akan mendukung peristiwa belajar dan memudahkan mengjngat apa yang telah dipelajari, karena struktur kognitif yang baik akan memudahkan seseorang belajar dengan jalan membantu pebelajar untuk memasukkan sejumlah informasi dan konsep (Sastrawijaya, 1988:92).Pada materi pelajaran tertentu struktur kognitif mencerminkan seberapa baik siswa mengorganisir pemahaman konseptualnya.

Pengorganisasian pemahaman konseptual dengan baik akan membantu kebermaknaan balajar siswa, sehingga siswa lebih mudah memahami materi pelajaran IPA yang sedang dipe;ajarinya. Tetapi sayangnya, hal ini jarang dilakukan. Seperti hasil penelitian yang dikemukakan oleh Carey dan flavell (dalam Pendley, 1994:9) menyebutkan bahwa terbatasnya kemampuan siswa dalam belajar kimia lebih cenderung mencerminkan hilangnya kerangka kerja konseptual yang diorganisir dengan baik daripada terbatasnya fungsi otak yang disebabkan terbatasnya operasi kognitif.

Menurut Ausubel (1963:22) dalam teorinya "Meaningful Verbal Learninng", belajar bermakna (meaningful learning) merupakan suatu proses dalam belajar dimana informasi baru dikaitkan pada konsep-konsep relevan yang telah ada dalam struktur kognitif pebelajar. Keuntungan belajar bermakna dibandingkan belajar hafalan adalah informasi yang dipelajari lebih mudah dipahami dan akan lebih lama diingat serta memudahkan proses belajar berikutnya.

Menurut Novak (1984:609), salah satu cara untuk mengembangkan strategi belajar bermakna adalah menggunakan peta konsep atau pemetaan konsep. Peta konsep yang diperkenalkan oleh Novak, merupakan suatu alat yang efektif untuk menghadirkan secara visual hirarki generalisasi- 
generalisasi dan untuk mengekapresikan keterkaitan proposisi dalam system konsep-konsep yang saling berhubungan. Novak dan Gowin (dalam Ebenezer, 1992:465) menyakini bahwa pemetaan konsep akan membantu para siswa untuk membangun kebermaknaan konsep-konsep dan prinsip-prinsip yang baru dan lebih kuat pada suatu bidang studi.

\section{B. Pembelajaran IPA di SD/MI}

Menurut Connor (dalam Rowe, M.B.,1990;6) tujuan pendidikan IPA untuk pendidikan dasar meliputi 4 tujuan utama yaitu: menyiapkan individu yang mampu menggunakkan sains bagi peningkatan tarap hidup dan menghadapi perkembangan teknologi ( personal needs), menanamkan tanggung jawab terhadap isu-isu social yang berkaitan dengan sains (social issues), menanamkan kesadaran akan sifat dan ruang lingkup sains yang berhubungan dengan pengembangkan bakat dan minat ( career education awareness), memberi landasan bagi siswa yang akan mendalami sains secara akademik dan professiona (academic preparation ). Selain itu tujuan pembelajaran IPA dalam kurikulum SD/MI 2004 antara lain

menguasai konsep sebagai produk IPA yang berupa konsep, prinsip, dan hukum; pengembangan ketrampilan berpikir melalui proses sains serta pengembangan sikap yang positif seperti mengakui kebesaran tuhan Yang Maha Esa, jujur, dapat bekerja sama, dan lain sebagainya .

Dari tujuan tersebut tampak bahwa target pembelajaran IPA tidak hanya sekedar dikuasainya pengetahuan IPA, tetapi melalui pembelajaran IPA siswa juga diharapkan mengembangkan ketrampilan serta mengembangkan aspek kepribadian sebagai proses untuk membentuk manusia seutuhnya (Salim dalam Soedjatmoko,1991; Hinduan,1999; Loucks-Horsley,1990).

Keterampilan yang dilatihkan di SD/MI adalah keterampilan proses sains yang meliputi: mengobservasi, mengelompokkan, mengukur, membuat inferensi dan membuat perkiraan, melakukan percobaan (Gega, 1994). Keterampilan proses sains dapat dilatihkan melalui kegiatan mindson/hands-on (Carin, 1993). Dengan melatihkan keterampilan proses sains di SD/MI diharapkan siswa tidak hanya menguasai keterampilan manipulatif terhadap obyek tetapi juga dapat meningkatkan keterampilan berfikir. Hal ini sesuai dengan pandangan Piaget (dalam Good, 1976) bahwa ketika seorang anak melakukan manipulasi terhadap suatu obyek, proses mental tetap terjadi pada saat yang bersamaan.

Berdasarkan jenjang dan karakteristik perkembangan intelektual anak seusia siswa SD maka penyajian konsep dan ketrampilan dalam pembelajaran IPA harus dimulai dari nyata (konkrit) ke abstrak; dari mudah ke sukar; dari sederhana ke rumit, dan dari dekat ke jauh. Dengan kata lain, mulailah dari apa yang ada pada/di sekitar siswadan yang 
dikenal, diminati serta diperlukan siswa. Secara psikologis anak usia SD berada dalam dunia bermain. Tugas guru adalah menciptakan dan mengoptimalkan suasana bermain tersebut dalam kelas sehingga menjadi media yang efektif untuk membelajarkan siswa dalam IPA. Sesekali tidak boleh terjadi, pembelajaran IPA di SD justru mengabaikan apalagi menghilangkan dunia bermain anak. Pembelajaran IPA akan berlangsung efektif jika kegiatan belajar mengajarnya mampu mencitrakan kepada siswa bahwa kelas adalah tempat untuk bermain, aman dari segala bentuk ancaman dan hambatan psikologis, serta memfasilitasi siswa untuk secara lugas mengemukakan dan mencobakan ide-idenya.

Siswa akan memiliki kemampuan berpikir yang baik apabila siswa memiliki banyak prngalaman belajar. Carin \& Sund (1989:22) menyatakan bahwa memperkaya pengalaman yang bermakna menimbulkan kaya akan berfikir. Sementara Tyler (1949:72) berpendapat bahwa pengalaman belajar sangat membantu siswa dalam memperoleh informasi yang fungsional sehingga akan sangat bermanfaat dalam mempersiapkan siswa menghadapi permasalahan.Proses pembelajarn yang memberikan kesempatan bagi siswa untuk memperoleh keterampilan-keterampilan dalam pemecahan masalah akan mewujudkan pengembangan kemampuan berfikir. Oleh karena itu mengajar untuk berfikir, berarti memberikan kesempatan bagi siswa untuk melatih penggunaan konsep-konsepk dan skema-skema dasar fenomena berfikir. Pengalaman ini diperlukan supaya siswa mwmiliki struktur konsep yang dapat menberikan solusi terhadap sesuatu permasalahan. Dengan kata lain kemampuan berfikir akan membekali siswa dengan mekanisme yang diperlukan untuk menganalisis suatu permasalahan.

Anak kelas V SD/MI dari segi usia berada pada masa transisi antara tahap perkembangan operasional konkrit akhir dan operasional formal awal yang memiliki cirri sudah dapat berfikir rasional dan mulai mampu berfikir abstrak(Pappalia \&Olde, 1992). Sehingga dalam permbelajaran IPA di kelas $\mathrm{V}$, anak masih belum sepenuhnya dapat melepaskan kebiasaan berfikir konkritnya, sehingga memerlukan pengalaman-pengalaman yang bersifat fisik. Misalnya melakukan observasi langsung terhadap suatu objek, tetapi kadarnya dikurangi. Sebagai gantinya, mulai diperkenalkan symbol- symbol dan mulai dilatih untuk membuat hubungan hubungan yang logis antar objek maupun konsep. Tampaknya kemampuan berpikr rasional seharusnya sudah dimiliki pada tahap ini (Pappalia \& Olds,1992), sehingga pengetahuan yang bersifat abstrak sudah dapat diperoleh tanpa harus selalu menghadirkan fakta secara langsung.

Pembelajaran IPA yang efektif juga dicirikan oleh tingginya kadar on-task (aktivitas edukatif) dan rendahnya off-task (aktivitas non edukatif) siswa dalam pembelajaran. Menurut (Horsley 1990;42) salah satu upaya 
untuk meningkatkan kadar on-task siswa adalah dengan mengembangkan kegiatan hands-on (psikomotor) dan minds-on (kognitif efektif),melalui sejumlah ketrampilan (skill) yang dilakukan siswa dalam kelas. Menurutnya ada empat jenis ketrampilan: ketrampilan laboratorium (laboratory skills), ketrampilan intelektual (intellectual skills), ketrampilan berpikir dasar (generic thinking skills) dan ketrampilan berkomunikasi (communication skills). Keempat jenis ketrampilan ini tidak lain merupakan pengelompokan dari ketrampilan proses IPA yang sudah kita kenal.

Dalam menyelenggarakakn pembelajaran IPA dengan pendekatan dan model apapun guru harus tetap pro aktif sebagai fasilitator; mau memonitor seberapa besar kadar on-task siswa, seberapa banyak ketrampilan dan sikap ilmiah siswa yang dapat dikembangkan, dan sejauh mana konsep-konsep IPA dikuasai siswa. Jika itu tercapai secara optimal dalam pembelajaran maka dapat dipastikan bahwa pembelajaran IPA yang diselenggarakan guru adalah pembelajaran IPA yang efektif.

\section{Ketrampilan Berpikir Rasional dan Pengembangannya}

Kata " berpikir rasional" oleh orang Indonesia diberi arti harfiah secara sangat sederhana, yaitu berfikir sesuai dengan sistem logika atau berpikir sesuai dengan akal sehat. Akan tetapi pada kenyataannya berpikir rasional merupakan salah satu alas an yang menjadikan orang mau mengikuti pendidikan seumur hidupnya, tidak hanya di Indonesia tetapi di seluruh dunia. Walaupun ketrampilan berpikir rasional setiap orang berbeda, akan tetapi ada indicator-indikataor yang dapat dikenali untuk menentukan apakah seseorang telah memiliki ketrampilan berpikir rasional. The Educational Polcies Commision dari Amerika Serikat (Lawson, 1979) menentukan sepuluh ketrampilan berpikir rasional yang meliputi:

1. Mengingat (recalling) apa yang telah didapat sebelumnya baik berupa pengalaman maupun pengetahuan untuk dapat digunakan dalam membangun pengetahuan yang lebih luas.

2. Berimajinasi (imagining) yakni kemampuan untuk menciptakan bentuk baru dari suatu pengetahuan atau membuat karya sebagai ekspresi seni

3. Mengelompokkan (classifying0 melibatkan kemampuan memisahkan atau menggabungkan berdasarkan satu ataupun seperangkat atribut untuk dijadikan criteria.

4. Menggeneralisasikan (generalizing) melibatkan kemampuan mengenali cirri individu atau kejadian yang dapat digunakan untuk mengenali kelompok yang lebih besar atau lebih umum. 
5. Membandingkan (comparing) seperti generalisasi kemampuan ini menuntut kemampuan untuk mengenali ciri individu atau kelompok yang memiliki keteraturan atau pola tersendiri dan mengenali bahwa kelompok lain memiliki pola yang berbeda.

6. Mengevaluasi (evaluating) melibatkan kemampuan untuk mengambil keputusan dalam memilih berdasarkan hasil membandingkan atau menggeneralisasikan.

7. Menganalisis (analyzing) adalah melakukan pengelompokan membandingkan serta menggeneralisasikan data atau kejadian'

8. Mensitesis (synthesizing) melibatkan kemampuan mengelompokan menggeneralisasikan membandingkan dan mengevaluasi sehingga menghasilkan suatu definisi sendiri atau mungkin juga menghasilkan suatu kreteria pengelompokan baru.

9. Mendeduksi (deducing) selalu melibatkan kemampuan mengelompokkan dan menggeneralisasikan fakta atau data yang sangat terbatas untuk dapat membentuk suatu ide yang unik.

10. Membuat inferensi (inferring) yang melibatkan seluruh kemampuan pada tingkat sebelumnya.

Untuk dapat mengembangkan keterampilan berpikir rasioanal, perlu dipahami karakteristik terlebih dahulu. Karakteristik dari keterampilan berpikir rasional adalah: berjenjang, artinya seseorang yang memiliki ketrampilan membuat kesimpulan (inferring) secara otomatis telah menguasai ketrampilan yang tingkatannya lebih rendah; dapat diukur tingkat penguasaannya; dapat dilatihkan melalui pembelajaran.

Ketrampilan berfikir rasional terdiri dari 10 jenis ketrampilan seperti yang telah diungkakan diatas, menunjukkan bahwa ketrampilan terakhir hanya dapat dikuasai jika keterampilan sebelumnya telah dikuasai. Sebagai contoh keterampilan mengevaluasi tidak akan dimiliki jika keterampilan membandingkan, menggeneralisasikan serta mengelompokkan tidak dikuasai. Konsekuensinya untuk melatihkan suatu jenis keterampilan berfikir rasional tertentu, perlu diketahui terlebih dahulu keterampilan apa yang telah dimiliki untuk dijadikan sebagai titik tolak dalam meningkatkan keterampilan berfikir rasional.

Keterampialn berfikir rasional dapat diajarkan (Pappalia \& Olds, 1992). Untuk dapat mengggajarkan keterampilan berfikir rasional diperlukan pengetahuan, sedangkan untuk dapat mengetahui sesuatu diperlukan pemikiran (Kamii dalam Lawson, 1979). Dengan kata lain kemampuan berfikir tidak akan dapat dikembangkan tanpa ada sesuatu yang dipikirkan(Lawson,1979). Dalam hal ini tampak bahwa konsepkonsep dalam IPA diperlukan untuk mengajarkan keterampilan berfikir (Seiger-Ehrenberg dalam Costa,1985). 
Menurut Novak (dalam Lawson, 1979:205) jika guru memutuskan akan menggunakan konsep sebagai wahana untuk mengajarkan keterampilan berfikir rasional maka guru dapat memulainya dengan membuat perencanaan mengajar, yang didahului dengan analisis materi pembelajaran untuk menemukan mayor dan konsep subordinat, kemudian dibuat bagan konsepnya. Dengan cara tersebut diharapkan siswa dapat lebih mudah memahami hubungan antar konsep, karena kumpulan konsep terorganisasi dengan baik dan bermakna. Susunan konsep-konsep pada peta konsep yang akan dibahas dalam kegiatan pembelajaran dapat disusun bersama guru lain atau dapat juga disusun berdasarkan kesepakatan antara guru dan siswa.

Menurut Herron (1977) bahwa konsep-konsep IPA dapat dikelompokkan berdasarkan atribut-atribut konsep menjadi 7 kelompok yaitu:

1. Konsep konkrit, yaitu konsep yang contohnya dapat dilihat, misalnya air, bunga.

2. Konsep abstrak, yaitu konsep yang contohnya tidak dapat dilihat, misalnya atom, ion ,reproduksi.

3. Konsep dengan atribut kritis yang abstrak tetapi contohnya dapat dilihat.

4. Konsep yang berdasarkan suatu prinsip, misalnya campuran, persamaan gerak, kekerabatan.

5. Konsep yang melibatkan penggambaran symbol, misalnya rumus kimia, kuat arus, laju reaksi.

6. Konsep yang menyatakan sifat, misalnya eksplosif, panas, dingin.

7. Konsep yang menunjukkan atribut ukuran, misalnya kalori.

Penggelompokkan konsep dilakukan berdasarkan atribut yang dimiliki oleh setiap konsep. Setelah konsep-konsep dikelompokkan berdasarkan jenisnya, maka perlu dicari hubungannya dengan konsep lain yang dinyatakan dalam bentuk peta konsep. Berdasarkan peta konsep akan lebih mudah bagi guru untuk menentukan strategi pembelajran yang akan digunakan.

Dengan menggunakan peta konsep, keterampilan berfikir rasional dapat diajarkan dengan cara menghadapkannya pada masalah, memberinya pertanyaan, serta melihat bentuk respon yang muncul (Costa,1985). Masalah yang diberikan bisa berupa fenomena baru (Lawson, 1979), mempertentangkan dua hal atau menimbulkan keraguan (Torrance dalam Lawson, 1979) atau dengan cara memperlihatkan perlakuan pada suatu obyek (Kamii dalam Lawson, 1979). Masalah tersebut akan menimbulkan konflik dalam pikiran siswa, sehingga terjadi disekuilibrasi 
dengan cara memberikan kesempatan untuk melakukan eksplorasi dan memberikan penguatan, jika keterampilan berfikir rasional sudah mulai tampak.

\section{Peta Konsep untuk Belajar IPA}

Pembelajaran IPA/Sains di SD/MI akan lebih bermakna apabila guru mengetahui konsep-konsep yang telah dimiliki para siswa. Menurut Novak (1984) alat yang dapat dipakai untuk mengembangkan strategi belajar bermakna kepada siswa adalah peta konsep atau pemetaan konsep. Pengertian peta konsep, ciri-ciri peta konsep, cara menyusun peta konsep dan kegunaan dari peta konsep adalah sebagai berikut

\section{Pengertian Peta Konsep}

Novak (1984: 609) menyatakan bahwa peta konsep merupakan suatu alat yang efektif untuk menghadirkan secara visual hirarki generalisasi- generalisasi dan mengekpresikan keterkaitan proposisi dalam sistem konsep-konsep yang saling berhubungan, yang merupakan ungkapan pemahaman konseptual siswa. Lebih lanjut dikataka bahwa peta konsep dimaksudkan untuk mengggambarkan hubungan yang bermakna antara konsep-konsep dalam bentun proposisi-proposisi. Sedangkan proposisi adalah dua atau lebih konsep yang dihubungkan dengan katakata sehingga membentuk suatu kalimat bermakna. Dalam bentuk yang paling sederhana, peta konsep terdiri atas dua konsep yang dihubungkan dengan satu kata untuk membentuk suatu proposisi. Misalnya lidah (indera pengecap) mempunyai papila, menunjukkan suatu peta konsep sederhana yang membentuk proposisi tentang konsep lidah dan papila.

Sejalan dengan pendapat Novak, Horton dan Philip (1993) mengatakan bahwa peta konsep adalah alat instruksional berbentuk bagan dan menunjukkan adanya hubungan antar konsep. Peta konsep membentuk hirarki yaitu konsep paling umum ada di puncak dan yang paling tidak inklusif berada di bagian bawah peta. Dalam suatu peta konsep terdapat konsep-konsep dan kata penghubung. Kata penghubung menerangkan bagiamana hubungan konsep berkaitan satu sama lain. Konsep yang inklusif (umum) berada dipuncak peta, dan konsep yang kurang inklusif (khusus) berada dibagian bawah peta.

Belajar bermakna akan lebih mudah berlangsung bila pengetahuan baru yang lebih khusus dikaitkan dengan konsep lama dan lebih umum yang sudah ada dalam struktur kognitif siswa. Sehingga peta konsep dikatakan baik apabila peta konsep tersebut dapat menunjukkan hirarki konsep-konsep (Susilo, 1999:32).Dengan peta konsep berarti mendorong untuk mengembangkan pengorganisasian pemahaman konseptual menjadi lebih baik. Siswa yang membangun kerangka kerja konseptual yang diorganisir dengan baik, berarti siswa tersebut telah berhasil mengembangkan strstegi belajar secara bermakna. 
Peta konsep yang dibuat siswa mempunyai kemungkinan berbeda antara siswa yang satu dengan siswa yang lain. Walaupun berbeda tetapi hirarki peta konsep yang dihasilkan tetap memperlihatkan keterkaitan yang bermakna bagi penyusun peta konsep tersebut. Hal inilah yang menunjukkan perbedaan individu. Perbedaan individu ini disebut idiosinkratik yang berarti bahwa kebermaknaan konsep-konsep adalah khas untuk setiap orang. Dan peta konsep dikatakan baik adalah peta konsep yang terdiri dari banyak konsep yang mempunyai banyak proposisi dan tingkatan abstraksi dalam hirarkinya mempunyai garis penghubung yang menunjukkan hubungan antar konsepnya, serta contohcontoh yang menyertainya.

\section{Ciri-ciri Peta Konsep}

Peta konsep mempunyai 4 ciri penting yang harus diperhatikan oleh setiap guru. Keempat cirri tersebut menurut Dahar (1988:125) adalah sebagai berikut: pertama, peta konsep atau pemetaan konsep ialah suatu cara memperlihatkan konsep-konsep dan proposisi-proposisi suatu bidang studi misalnya mata pelajaran IPS, IPA, matematika, bhs Indonesia dan lain-lain. Dengan membuat sendiri peta konsep, siswa dapat melihat dan memahami suatu mata pelajaran dengan lebih jelas dan bermakna.

Kedua, suatu peta konsep merupakan gambar dua dimensi dari suatu bidang studi atau suatu bagian dari bidang studi. Peta konsep bukan hanya menggambarkan konsep-konsep yang penting melainkan juga memperlihatkan hubungan antar konsep. Gambar yang memperlihatkan hubungan-hubungan proposional antar konsep yang dipelajari. Hal inilah yang membedakan belajar secara bermakna dibandingkan belajar dengan cara mencatat pelajaran tanpa memperlihatkan hubungan antar konsepkonsepg Sehingga belajar tersebut hanya dengan memperlihatkan gambar satu dimensi saja.

Ketiga, mengenai cara menyatakan hubungan anatara konsepkonsep paling inklusif terdapat pada puncak lalu menurun sampai konsepkonsep yang lebih khusus serta contoh-contohnya. Tidak semua konsep mempunyai bobot yang sama, ini berarti bahwa ada beberapa konsep yang lebih inklusif daripada konsep-konsep lainnya.Keempat, peta konsep pada akhirnya akan memperlihatkan susunan hirrarkis. Bila dua atau lebih konsep ditempatkan di bawah satu konsep yang paling inklusif, akan berbentuk hirarki pada konsep berikutnya.

\section{Cara Menyusun Peta Konsep}

Berdasarkan kurikulum SD/MI tahun 2004,mata pelajaran IPA/Sains untuk kelas V, salah satu pokok bahasan adalah alat indera. Pada pokok bahasan alat indera terdapat konsep-konsep yang bersifat abstrak, yang menjelaskan bagian-bagian lidah dan fungsinya. Salah satu subkonsep yang bersifat abstrak adalah bagian lidah yang peka terhadap 
rangsang dan cara kerja lidah. Untuk membantu memudahkan mempelajari konsep tersebut dibutuhkan alat Bantu, yaitu peta konsep atau pemetaan konsep.

Menyusun peta konsep dapat dilakukan dengan mengikuti beberapa langkah seperti disarankan oleh Novak (dalam Dahar, 1988:126) sebagai berikut

1. Memilih dan menentukan suatu bahan bacaan

Bahan bacaan dapat dipilih dari buku pelajaran dan bahan bacaan lain, seperti buku catatan, LKS.

2. Menentukan konsep-konsep yang relevan.

3. Megurutkan konsep-konsep tersebit dari yang paling inklusif sampai paling tidak inklusif dan contoh-contoh.

4. Menyusun dan menuliskan konsep-konsep yang sudah ditentukan di kertas.

Memetakan konsep-konsep yang telah ditentukan dengan berdasarkan criteria bahwa konsep yang paling inklusif berada dipuncak. Sedangkan konsep-konsep yang berada pada tingkatan abstraksi yang sama diletakkan sejajar satu sama lain, serta konsep yang lebih khusus diletakkan dibawah konsep yang lebih umum.

5. Menghubungkan konsep-konsep yang sudah ditentukan dengan kata penghubung tertentu untuk membentuk proposisi dan garis penghubung.

6. Apabila peta konsep telah selasai maka diperiksa kembalenjadi konsep-konsep dan keterkaitan antara konsep yang satu dengan yang lain. Langkah terakhir adalah menyusun kembali peta konsep tersebut agar mejadi lebih baik dan berarti.

Menurut Novak bahwa dalam menyusun peta konsep akan bermanfaat sekali dengan menggunakan tanda panah yang berfungsi untuk menunjukkan bahwa terdapat hubungan yang bermakna antara konsep yang satu dengan konsep yang lain. Hubungan tersebut juga ditunjukkan dengan kata-kata yang terkait menjadi satu arah. Selain itu label penghubung dalam peta konsep adalah sangat penting. Diharapkan dengan adanya label para pembaca peta konsep dapat memahami keterkaitan antara konsep-konsep dalam peta konsep.

\section{Kegunaan Peta Konsep}

Peta konsep memegang peranan penting dalam belajar bermakna yaitu sebagai alat yang dapat digunakan dalam pembelajaran. Peta konsep dapat digunakan dalam berbagai mata pelajaran untuk meningkatkan prestasi belajar siswa (Susilo,1999:33). Selain itu peta konsep juga dapat 
digunakan untuk memudahkan siswa dalam mempelajari konsep-konsep yang abstrak dan membentuk landasan berfikir terhadap setiap materi pelajaran.

Peta konsep mempunyai banyak kegunaan mulai dari perencanaan kurikulum, pengajaran sampai untuk evaluasi hasil belajar mengajar. Peta konsep juga dapat diterapkan dalam berbagai tujuan, antara lain mengetahui konsep awal yang telah dipahami siswa, menolong siswa dalam mempelajari cara belajar siswa, untuk mengungkapkan terjadinya miskonsepsi pada diri siswa, sebagai alat evaluasi (Dahar, 1988:129-132).

Menurut Novak (1984:609) bahwa peta konsep dapat membuat jelas gagasan pokok bagi guru dan siswa yang sedang memusatkan perhatian pada satu pokok bahasan, memberikan peta untuk menunjukkan arah keterkaitan konsep-konsep menjadi suatu proposisi yang mempunyai arti, sebagai ringkasan skematik tentang sesuatu yang sedang dipelajari.

Peta konsep dapat dipergunakan guru sebagai petunjuk dalam memahami hubungan anntara ide-ide yang penting dengan rencana pembelajaran. Sedangkan bagi siswa peta konsep dapat digunakan untuk membantu memahami dan mengingat sejumlah informasi baru (Martin, 1994:12). Selain itu berdasarkan hasil penelitian didaptkan bahwa peta konsep sebagai alat pembelajaran dapat meningkatkan kemampuan siswa dalam mengingat konsep dalam jangka panjang(Cliburn, 1990), dan meningkatkan prestasi akademis serta sikap siswa (Horton dkk, 1993).

Peta konsep yang digunakan dalam proses pembelajaran telah terbukti memberikan banyak manfaat dan dapat digunakan untuk berbagai keperluan. Tetapi Novak (1984) mengingatkan bahwa peta konsep menjadi tidak berarti bagi siswa yang belum terbiasa dengan cara belajar bermakna. Siswa yang sudah terbiasa belajar dengan cara hafalan tidak akan memberikan dampak seperti yang diharapkan. Sehingga kebiasaan belajar bermakna harus lebih ditekankan pada siswa dengan cara menyajikan materi pelajaran secara terstruktur dan memberikan pengalaman-pengalaman belajar yang memberikan kesempatan siswa untuk mengembangkan konsep melalui pemetaan konsep.

Dengan kata lain bahwa pada pembelajaran menggunakan peta konsep harus memperhatikan konsep awal yang dimiliki siswa dan guru harus melatih siswa supaya terampil membuat peta konsep sebelum pembelajaran dengan peta konsep dipilih dalam pembelajaran. Hal tersebut disebabkan bahwa cara pembuatan peta konsep tidak sulit tetapi memerlukan latihan yang berulang kali sehingga diharapkan siswa dapat menerapkan dengan tanpa hambatan selama proses pembelajaran berlangsung dan kebiasaan belajar bermakna dapat ditanamakan dalam diri siswa. 


\section{E. Contoh Peta Konsep}

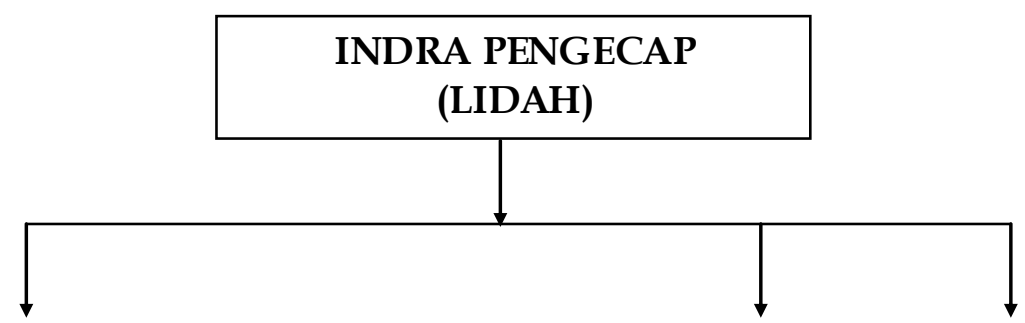

Bagian lidah yang peka

terdapat cara kerja lidah

terhadap rasa

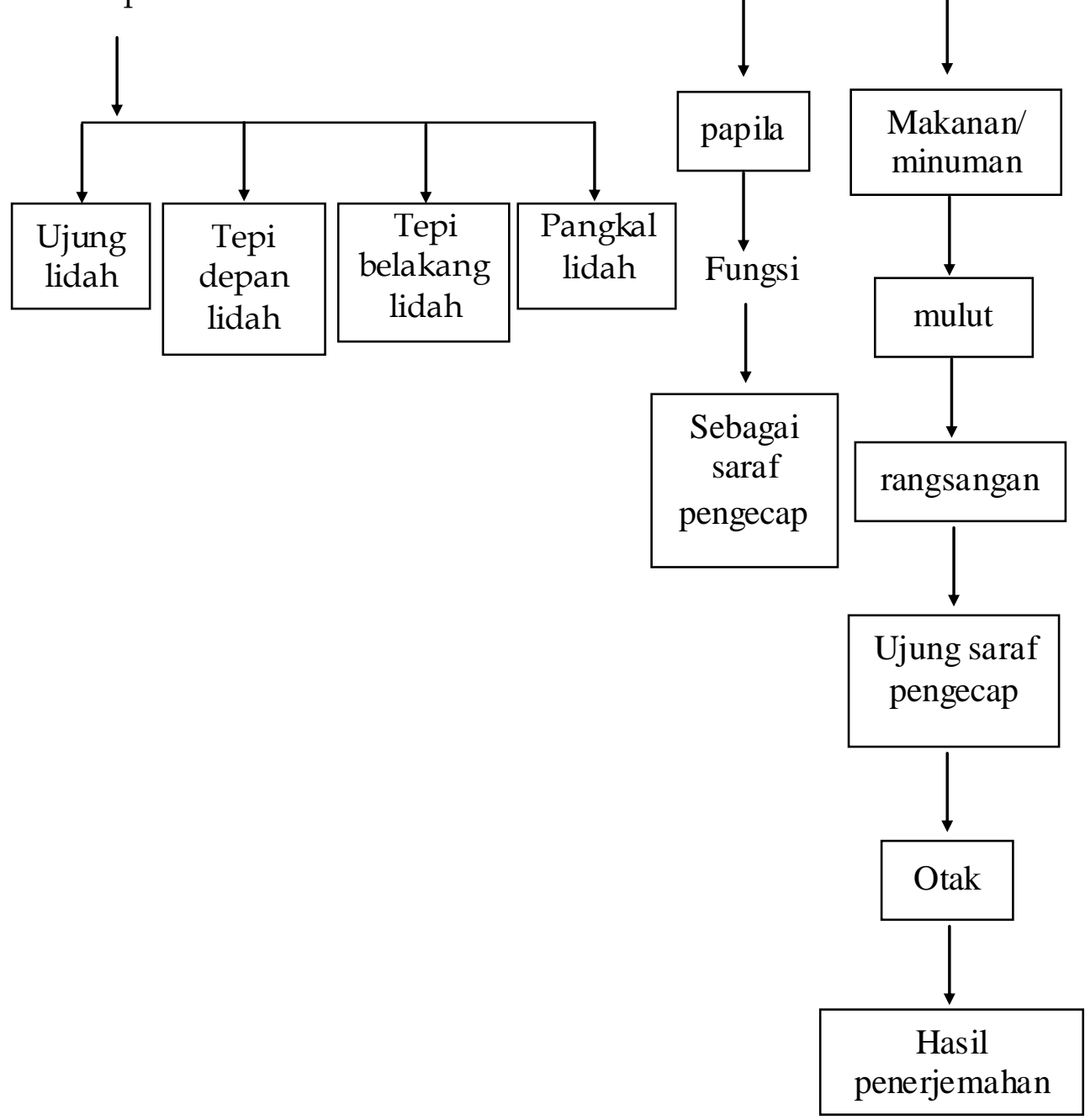




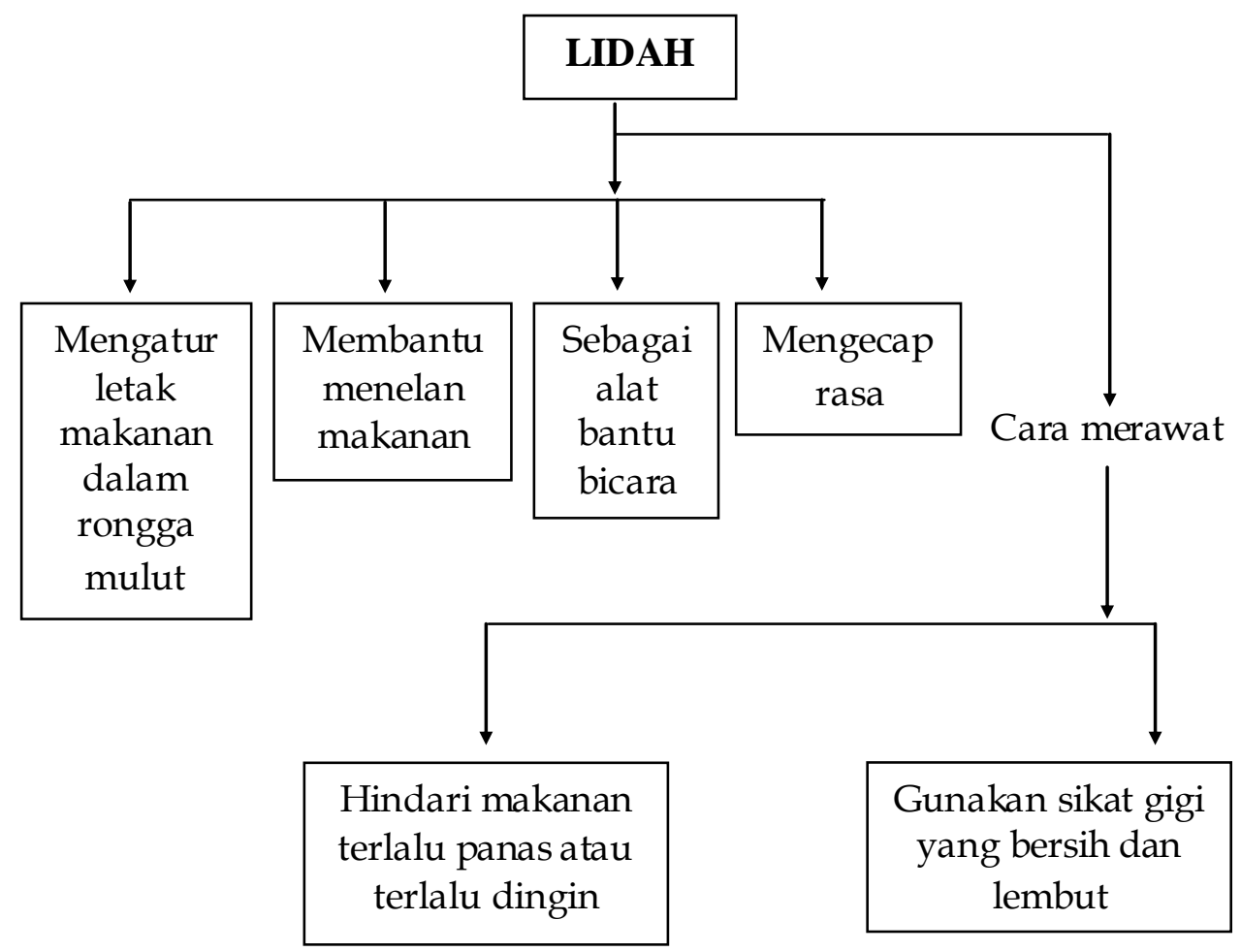

\section{F. Penutup}

Materi IPA/Sains kelas V pada pokok bahasan indera mengandung banyak konsep penting dan saling berhubungan. Untuk membantu siswa memudahkan memahami konsep tersebut maka dapat menggunakan media peta konsep. Dengan menggunakan media peta konsep diharapkan dapat mengorganisir konsep agar dapat meningkatkan penguasaan konsep indera dan terjadi kebermaknaan belajar bagi siswa. Penggunaan media peta konsep dapat dikembangkan pada akhir pembelajaran. supaya keterkaitan antara konsep-konsep yang baru dipelajari akan lebih mudah dipahami dengan lebih bermakna. Dengan mengembangkan peta konsep secara utuh maka siswa akan dapat memahami keterkaitan yang baru diantara konsep-konsep yang sebelumnya tidak terlihat keterkaitannya

Pembelajaran IPA/Sains dengan media peta konsep juga dapat meningkatkan aspek keterampilan berfikir rasional siswa yang meliputi aspek mengingat, mengelompokkan, membandingkan, menggeneralisasikan, mengevaluasikan, menganalisis, mensintesis dan aspek keterampilan proses sains yaitu menggelompokkan, mengkomunkasikan, dan membuat inferensi. Hal ini dapat dicapai apabila dalam pembelajaran memberikan kesempatan kepada siswa untuk mengamati, memanipulasi obyek yang diamati, menyusun data, bertanya serta menjawab pertanyaan. 


\section{G. Daftar Pustaka}

Ausubel, D.P. 1963. The Psycohology of Meaningful Verbal Learning. New York: Grunner \& Stratton, Inc.

Carin,A.A. \& Sund,R.B.1989. Teaching Science Through Discovery. Columbus: Merrill Publishing Company

Connor, J.V. 1990. Naïve Conceptions and the School Science Curriculum. Washington : National Science Teachers Association.

Costa, Arthur. L (ed). 1985. Developing Minds A Resource Book for Teaching Thinking. Virginia: Association for Supervision and Curriculum Development.

Cliburn, J.W. 1990. Concept Maps To Promote Meaningful Learning. Journal of College Science Teaching, 15(4): 212-217

Emil Salim. 1991. Sumber Daya Manusia dalam Perspektif. Mencari Strategi Pengembangan Pendidikan Nasional Menjelang Abad XXI. 1991. Jakarta: Grasindo

Dahar, R.W. 1988. Teori-teori Belajar.Jakarta: Depdikbud Dirjen Dikti P2LPTK.

Ebenezer, J.V. 1992. Making Chemistry Learning More Meaningful. Journal of Chemical Education, 69(6): 464-467

Good, R.G. 1977. How Children Learn Science. New York: Macmillan Publishing Co

Herron, J.D.et all. 1977. Problem Associated with Concept Analysis. Journal Science Education.6(12)

Horton dan Philip, B., Mc Conney, Andrew A. 1993. An Investigation of the Efektivitas of Concept Mapping as an Instructional Tool. Science Education, 77(1): 95-115

Kammii,C. 1979. Teaching for thinking and Creativityo: A Piagetian of view dalam 1980 Aets Year Book.1980. Science Education Information Report. The Ohio State University

Lawson, Anton.E. 1979. 1980 AETS Yearbook the Psychology of Teaching for Thinking and Creativity. Ohio: Eric Clearinghouse for Science, Mathematics, and Environmental Education.

Loucks, H.S. 1990. Elementary School Science for the'90s. Andover,Massachusetts: The NETWORK,Inc.

Martin,D.J. 1994. Concept Mapping As to Lesson Planning: A Longitudinal Studi, Journal of Elementary Science Education.6(2): 11-30 
Novak, J.D. Application of Advances in Learning Theory and Philosopy of Science to Improvement of Chemistry Teaching. Journal of Chemical Education.6(7):607-612

Novak, Joseph.D. 1979.Meaningful Reception Learning as a Basis for Rational thinking dalam 1980 AETS Yearbook 1979. Science Education Information Report. The Ohio State University, 192-225

Papalia, Diane.E. \& Olds, Sally.W. 1992. Human Development. New York: McGraw Hill Inc.

Sastrawijaya, Tresna.1988. Proses Belajar Mengajar. Jakarta: Depdikbud

Seiger-Ehrenberg,Sidelle.1985. Concept Development dalam Developing Minds A Resources Book for Teaching Thinking.Virginia:Association for Supervision and Curriculum Development.

Sumaji, dkk. 1998. Pendidikan Sains yang Humanistis. Yogyakarta : Kanisius

Susilo, H. 1988. Penggunaan Peta Konsep dalam Pengajaran Biologi. Majalah Eksakta, Edisi bulan Juli,9-17

Tyler, R.W. 1949. Basic Principles of Curriculum and Instruction. Chicago: The University of Chicago Press

Yager, Robert E.1991. The Constructivist Learning Model (Towards real reform in science education. Makalah untuk The National Science Teachers Association, North Washington. 